\title{
Breaking Away from Communism. Trauma, Resentment, Frustration - The Case of I. Negoițescu's Return from Exile
}

\author{
Prof. univ. dr. DIACONU A. Mircea \\ Universitatea "Ștefan cel Mare” din Suceava
}

\begin{abstract}
In his article "Breaking Away from Communism. Trauma, Resentment, Frustration - The Case of I. Negoițescu's Return from Exile", Mircea Diaconu aims at examining the way in which, after December 1989, Romanian literature bears the consequences of the traumas, frustrations and resentment experienced under the communist regime. Its post-revolutionary configuration is not only the result of the newly-gained freedom, which led to substantial mutations, but also the result of the pressures exerted by the past; just as it was unfathomable for the writers to reinvent themselves overnight, their options shaped and asserted in the long run could not undergo major changes either. Yet maintaining their legitimacy has become anachronic, as in I. Negoițescu's case.
\end{abstract}

Keywords: Ion Negoițescu, Communism, trauma, resentment, frustration.

Mention must be made from the outset that the focus of our examination will not consist in the literary creation per se, but in literary criticism; more precisely, we shall investigate the critical reception of I. Negoițescu's works. Bearing in mind that, in terms of topics addressed and types of discourse used, all throughout the ninth decade of the last century there was a confrontation between the prevailing approach of the immediate reality, the daily routine (this being the direct result of the tendency of being in line with the western literatures), and the already established validated literature, which was considered, even by its act of dismissal of the political system, as the latter's accomplice, we shall not focus on the politically committed literature nor on the writings found under the tutelage of the socialist realism, which were almost inherently excluded from the aesthetic canon of the time, falling under what may be called the dogmatic category; we shall neither focus on the literature which, on the opposite end, either dismissed any contextualisation, in the service of the aesthetic, or denounced the political system by resorting to allusive, parabolic, oblique language. Naturally, to a great extent, the abovecited extremes are theoretical and ideal. What is clear is that in the 1980's, as opposed not only to the dogmatic literature, but also to the aesthetic and parabolic ones, there was a literature of the pure fact, of the concrete reality 
written in an unfigurative language, often carrying subversive undertones. This kind of literature was denounced in the newspapers pertaining to the political system as antinational and "European" (a term obviously bearing negative connotations in this context).

We must also point out that in the 1980's the authority of literary criticism also came from a few voices which had made themselves heard since the early 1960's, in the attempt to free literature first from socialist realism, then from nationalism. Although they had received their education in the 60 's, they were supporters of the new literature (when any paradigm change made the literary and political establishment feel anxious and frightened) and, just as in the previous decades, of the aesthetic principle; these options implied breaking free from dogmatism and adhering to a European model, with all its implicit utopian and imaginary vision. They were politically connoted and used as political weapons. Even so, engaged in a concealed confrontation, the writer and the critic belonged to a world that was parallel to the political one. And while the political system continued its atrocities at a human level, writers and critics alike took refuge in the gratuitous pleasure they could take from the literary art. Yet a victory on the aesthetic level taking on the significance of a political victory was but an illusion, which nowadays could be synonymous of a diversion. If it could not resort to subversion or parabola, the means used by writers to undermine the political system, the literary criticism still had the possibility to promote the aesthetic. It is not by chance that the interpretation of certain writers from the previous ages was mainly done from an aesthetic angle, an implicit argument in supporting the contemporary literature. Bringing the artifice, the artistic refinement to the foreground and relegating the content to the background, was indirectly a plea for aestheticism and for the European values in art, whilst being a weapon against dogmatic literature.

Established on these principles, which derived their legitimacy from the communist regime, the Romanian literary criticism (let us accept for now this generalisation which, of course, has its disadvantages) does not redefine its condition after 1989, in the context of a free society. It fails to see the option for the aesthetic as circumstantial. In this light, the critical review of the literature from the communist period is at an impasse. Some critics consider it unnecessary, since the evaluation has been done according to valid aesthetic principles that transcend history, while others consider it mandatory, but do not have the necessary tools and experience to do that. The writers themselves must overcome an impasse, as the value was often given by the degree of artistic refinement (a good refuge for artists), or by the allusive language that required 
an effort of interpretation. Even some of the writers of the 1980's, whose aim seemed to be the subversion and denunciation of the flawed world of communism, stated after 1989 that their aim was actually literary-bound and not political. Under these circumstances the reaction of the young generation whose debut takes place after1989 and who opt for minimalism, sexuality, the naturalist transcription of the concrete world, etc., is understandable. There are thematic and language areas which were once forbidden and which, programmatically or not, elude or dismiss the aesthetic, replacing it with "content". They approach it in a different manner. Everything that used to pertain to the literarity of those times is forsaken.

After 1989 the literary world is divided into two different worlds, with divergent opinions on a series of important topics: literary reviewing, the contribution and the recovery of the writers in exile, the writers' commitment to politics. A solidary world (that of the valuable writers from the last decades of the communist regime united in the fight for the European values and for the aesthetic by the very strategies of confrontation with censorship) finds itself fractured all of a sudden, after having opted for irreconcilable values and tenets. There is a wide array of reactions triggered by the idea of recuperating the writers in exile, which leads to questions such as: Do they deserve to be part of / Can they reintegrate the Romanian literary phenomenon and be reintroduced in the values scales? Are their viewpoints and the hierarchies established in exile valid? Leaving this aside, critics are on opposite positions when it comes to evaluating the literature written during the communist years and analysing the relation established between literature, writers and politics. More precisely, while some of them consider that the literature written under the communist regime should be reread and re-evaluated, in order to assess, under the new free circumstances, the validity of the criticism and of the canon at that time, others are of the opinion that the hierarchies created in the communist regime are intangible and reviewing them would be undermining a set of national values. Moreover, as back then the writer had been forced to take refuge in the aesthetic (or to feign adherence to official politics by keeping silent if he did not belong to the official political structures), some maintain that the writer must be directly or indirectly involved, his silence being precisely the sign of their complicity with the authorities, while others maintain that he must remain isolated from the political turmoil, from any king of political engagement. Even today, almost three decades after the fall of communism, the theoretic backbone of the debates is mainly characterized by the options made right after 1989, many of the 
important critics of the communist age, who had militated for the autonomy of the aesthetic, adopting a conservative stance.

Ion Negoițescu, who makes the object of our paper, is implicitly a "victim" of this way of seeing things. Istoria literaturii române (The History of Romanian Literature), written in exile and published in Romania in 1991, amplifies these confrontations, being unanimously considered, since its publication, an aesthetic history of literature, which has led both to its denial and its unconditional appreciation.

His particularly active presence in the literary life between 1990 and 1992 (the texts published back then will posthumously lead to Scriitori români (Romanian Writers) could but create suspicion, discontent, frustrations. After all, someone who had not lived in Romania, who had had no contact with the literary life as such, was pronouncing principles and analysing and judging our literature based on an authority given by keeping the analysis criteria intact, uncontaminated by communism.

This situation escalates with Negoițescu's opinion on a sensitive topic considered sacred: Eminescu, Romanians' national poet. In a period of time characterized by dogmatism (the 1950's), Negoițescu had written a book about Eminescu (published only in 1968) which accomplished a radical shift in the points of interest of the poet's work. A visionary poet, just like the great German romantics, Eminescu had published numerous articles, which would be ideologically used throughout history both by the extreme right- and left-wing politics. Yet Negoițescu (just like Virgil Nemoianu) declares right after 1989 that Romanians suffer from the retrograde anti-European ideology of the great poet. This is why his pro-European activism and the values scales thus ensued become suspicious and amendable. Negoițescu is exposed to public opprobrium. Writing and publishing under these circumstances an aesthetic history of the literature is an attack on the national identity. Moreover, the accusations stem from prejudices regarding Negoițescu's biography, as well as from the tenets of the literary criticism before 1989.

These is another aspect of major importance. In 1990, before the publication of Istoria literaturii (The History of Literature), Negoițescu published a collection of articles with the title In cunoștință de cauză (Fully Informed), bearing the subtitle Texte politice (Political Pieces). With the exception of Manifestul (The Manifesto) from 1945, which acquired political significance, it included open letters, interviews and comments broadcasted by Negoițescu during his exile years on the Radio Free Europe and BBC. But even if his political texts represent literary manifestos and are the key to his critical views presented in his Istorie 
(The History) no correlation has been made between the ideas in this collection and the organisation principles and analysis criteria found in Istoria (The History). Istoria (The History) and Textele politice (Political Pieces) seemed to be two different facets of a double character, just like Dr. Jekyll and Mr. Hyde. The two books complete each other, and in order to understand Istoria (The History) one needs the keys provided by the political texts.

Comprehending Negoițescu's vision on literature and on literary criticism as well as his critical reception after 1990 implies getting acquainted with his intellectual trajectory. At the age of 22, Negoițescu (born in 1921) publicly shows his unreserved adherence to the tenets of the aesthetic autonomy, in line with Titu Maiorescu and E. Lovinescu, refusing all that is local, particular, national or ethnic. Right after the advent of communism on December $30^{\text {th }} 1947$, he adds to the purity of art the tragic moral values, in line with the German romanticism. This is what the magazine Revista Cercului (The Cenacle Journal) stands for, the young members of this circle, especially Negoițescu, deluding themselves that they could lead a biographical and literary life parallel to the political system. But at a time when the literature was supposed to be dogmatic and politically engaged, the accusation of aestheticism (levelled at Negoitescu since the Manifesto years) translates into years of imprisonment. In prison, in a space of liberty, he starts outlining his Istoria literaturii (The History of Literature) which he will publish in 1968, at a time which seemed synonymous of a literary renaissance. The fact that the so-called renaissance proved to be just an illusion is another story for another time. What is relevant is that, just as in the case of the Manifesto published in 1943/45?, which had offended the national and local sentiments and had generated aggressive reactions, even now Negoițescu's proposition is considered to be not only eccentric, but also an attack on national values. In all truthfulness, Negoițescu took pleasure in overthrowing taboos, regardless of their nature, including the moral ones: he was homosexual and had said it loud and clear. Anyway, in 1977 he joins Goma's Movement and is again imprisoned, when he tries to commit suicide for the third time. He considers suicide as a means of rising against the communist dictatorship. At last, he chooses to go into exile. He had published in Romania a few books of literary studies founded on his often nonconformist taste and, above all, in 1968 he had published the book Poezia lui Eminescu (Eminescu's Poetry) which, as a landmark for Eminescu's exegesis, would establish him as a critic against all the negative reactions on the part of his opponents. On this, Negoițescu experienced an undisclosed impasse. His magister, Lovinescu, who had promoted the synchronisation of the 
Romanian civilisation with the European one, was rather dismissive of Eminescu's creation, for, although he implicitely acknowledges Eminescu's central position in the Romanian table of values in the second half of the nineteenth century, he would not dedicate a special chapter to his work. Moreover, in his analyses of the history of civilisation and the history of the Romanian literature Lovinescu draws on their ideological component. Eminescu, as a conservative activist, had meanwhile become the point of reference for the nationalist ideology. He was profusely referred to, in terms of ideology, both in the interwar period and under the communist regime. Or Negoițescu uncovers in Eminescu's posthumous creation a deep-seated visionary drive that places the poet next to the great German romantics, making the critic elude his ideological stance (specific to all his literary creation, and implicitly to his poetry). This would have been irrelevant if in 1990, right after the fall of the communist dictatorship, in liberty, Negoițescu had not come back to Eminescu, stating that he represented a retrograde moment in Romania's European destiny. The same stance, acknowledged also by Virgil Nemoianu, triggers harsh reactions, both from the descendants of the upholders of the dogmatic ideology of the communist years, and from those who maintained that the hierarchy established in the communist years was intangible, that the writer had to be apolitical. Eminescu's admirers failed to see the basic contradiction, for Eminescu himself, not being a member of any political party, had promoted the conservative values in a way that was more radical than the one adopted by the politicians themselves. Anyway, in his Istoria (The History) published right about then, Negoițescu generally refrains from discussing Eminescu's ideology, preoccupied only with highlighting his visionary poetry. Or, considered aesthetic on grounds that it promoted the autonomy of the aesthetic (and not because it generated emotion), Negoițescu's Istoria (The History) is actually a political history, just like Lovinescu's had been between the wars. I would conclude by saying that, although the idea is already deeply rooted in the collective consciousness, the criticism from the early 1990's cannot free itself from its own obsessions and clichés. The exceptions only prove the rule and are ignored. Or Negoițescu fights against the very decadent aestheticism, against what becomes formal artifice, gratuitous beauty and pleasure. In addition to this, it has an activist dimension: one of the decisive judgement criteria consists in the way in which the book promotes the values of liberalism, democracy and individual freedom. Hence the overthrown values it entails.

As mentioned above, Istoria (The History) is preceded by $\hat{I}$ cunoștință de cauză. Texte politice (Fully Informed. Political Pieces), which published right after 
the Revolution in 1989 (the preface dates back to January 31 ${ }^{\text {st }} 1990$ ) and standing under the aegis of a sense of urgency imposed by the moral imperative of time, could only lead to confusion. The author explains: "These texts were first published, with the exception of one, in the foreign or the exile press, or were broadcasted on the Radio Free Europe and BBC. They are the product of my literary existence and of the historical period I lived in since my early age to the beginning of my old age" (Fully Informed 5) ("Textele aici adunate au apărut mai întâi, cu excepția unuia singur, în presa străină și în cea de exil, ori au fost difuzate prin posturile de radio Europa liberă și $B B C$. Ele țin de existența mea literară și de perioada istorică pe care am trăit-o din tinerețe până în pragul bătrâneții" - În cunoștință de cauză 5) (unless indicated otherwise, all translations are mine). Needless to say, these texts acknowledged by Negoițescu as the product of his literary existence are all political ones. The exception Negoițescu speaks about is "Manifestul Cercului Literar din Sibiu" ("The Manifesto of the Sibiu Literary Cenacle") - a political text. As explained by Negoițescu himself in interviews from his exile years and afterwards and as it is usually read, "Manifestul" ("The Manifesto") was the verbalisation of the rejection of the profascist tendencies in the Romanian literary field. Referring to this text in Scrisoarea către Paul Goma (Letter to Paul Goma), Negoițescu says that the manifesto "contributed in its own fashion to the demolition of the fascist ideology in the cultural field" ("și-a avut partea sa de contribuție la demobilizarea ideologiei fasciste în cultură") (15). As a matter of fact, beyond the plea for the supremacy of the aesthetic, this is how Lovinescu himself understood "Manifestul" ("The Manifesto"), since, in his answer, he invokes the death threats of the extreme right-wing. Yet, even though the option for the aesthetic had also been a political one, since 1945, the political component did not match at that time the scope it was to have in his last years of exile. In fact, this is the very mutation we are going to address in what follows.

What interests us is to pinpoint the transformations undergone by Negoițescu's option for the aesthetic and his type of political commitment. The conviction he had in the first years of communism when he believed he could take refuge in the aesthetic was followed by years of political imprisonment, then by dissidence, and in 1977 his adherence to Goma's Movement. Or, the principles promoted by Negoițescu are subject to change. Not only does he assign a different meaning to the aesthetic, but he also considers that the rights he had demanded and which had made him engage the fight against the system were irrelevant. The criticism he levels at the Romanian writers from this 
viewpoint and which stirred their backlash is the same Negoițescu bitterly levels at himself.

More precisely, on March $3^{\text {rd }} 1977$, one day before the devastating earthquake in Bucharest which would largely distort the meaning of his gesture, Radio Free Europe broadcasted Negoițescu's letter to Paul Goma, a message of support to the one who had become the public enemy of the communist regime. Beyond his patriotism that he highlights in unequivocal words ("Personally, I am not of those who intend to emigrate. There are too many things, both good and bad, joy and sorrow, tying me to this country where I was born and whose rights and glory were defended by my ancestors. ... I have dedicated my whole life to investigating and promoting the Romanian literature, which has brought me, as I was saying, much joy but also suffering: my works, on the one hand, and my prison years, on the other hand, are proof of that" ["Personal, eu nu fac parte dintre cei care intenționează să emigreze. Prea multe, și în bine și în rău, bucurii și suferințe, mă leagă de țara în care m-am născut și pentru drepturile și gloria căreia strămoșii mei au luptat. ... mi-am dedicat întreaga existență cercetării și promovării literaturii române, ceea ce mi-a adus, cum spuneam, destule bucurii, dar și suferințe: operele mele, pe de o parte, și anii de închisoare, pe de alta, stau mărturie"), he confesses in În cunoștință de cauză (Fully Informed) (13), Negoițescu brings to our attention the danger faced by the Romanian literature because of the censorship, the uniformisation created by the rhetoric of the regime and the literature that serves the nationalist propaganda. Negoițescu's statement motivating his gesture is noteworthy: "What is ... to me an essential issue is the general condition of present Romanian literature" ("Ceea ce constituie ... pentru mine o problemă esențială este starea generală a literaturii române în clipa de față") (14). Also noteworthy is his statement on his desperate fear that the Romanian literature is under threat given that the role of the language is perverted in a schizoid malfunctioning society in which everything is meant to be a cliché: "What poetry, what prose, worthy of the name of art, can come from this distorted function our language is now fulfilling? " ("Ce poezie, ce proză, demne de a fi numite artă, se vor mai putea naște din această numire degenerată care e limba noastră uzuală acum?") (16). He was thus engaged in a combat for the writers' freedom. A few months later (November 1977), when Anneli Ute Gabany asks him, actually expecting a positive answer, whether the letter to Goma can be considered "a political gesture", Negoițescu says without hesitation: "The aim of my letter to Goma was not intentionally political. I was first and foremost interested in casting light on a series of negative aspects in the field of literature and the literary organisation" 
("Țelul pe care l-am urmărit de fapt cu scrisoarea mea către Goma n-a fost expres politic. M-a interesat în primul rând să pun în lumină anumite aspecte negative în domeniul literaturii și al organizării literare") (19). The end of the interview reasserts this position and states his uncompromising commitment to Romanian literature. "I have yet to publish a book which might contradict my professional ethics; I have always served literature alone. If it is true that the Romanian literature must go on, then it is just as true that I must bear witness to its existence through my writings" ("N-am publicat până acum nici o lucrare în contradicție cu etica profesională; am servit întotdeauna numai literatura. Dacă e adevărat că literatura română trebuie să continue să existe, atunci e tot atât de adevărat că eu trebuie să-i atest existența prin scrisul meu") (20). Scrisoarea către Paul Goma (Letter to Paul Goma) is an essential document in Negoițescu's inner biography.

The following years, there is almost no interview where he does not express his regret, disappointment, even frustration, that the goal of his actions, like the one of the few Romanian writers who reacted to the political system, was only professional and literary. What he asks now from the Romanian writers is unwavering commitment not to the writer's individual (and professional) rights, but to the human rights and the values of modern Europe. Changing what had to be changed, the values the contemporary writers should fight for are similar to the ones advocated by the writers from 1840 who wanted the synchronisation of Romania with Europe. In an interview from August $18^{\text {th }}$ 1983 given to Anneli Ute Gabany, Negoițescu speaks about the fact that Goma had fought for the human rights and in his opinion now justice had been on his side, for "In order to win the freedom of creation and expression, to escape from humiliation and to have real moral authority in the eyes of their fellow citizens, the Romanian writers and artists must start fighting for the fundamental rights of the human being, and be in the centre of the political and social issues" ("Pentru a câștiga libertatea de creație și de expresie, pentru a scăpa de umilință și pentru a obține autoritatea morală adevărată în rândurile concetățenilor lor, scriitorii și artiștii români trebuie să pornească la lupta pentru drepturile fundamentale ale omului, să activeze în arena mai largă a problemelor politice și sociale") (27). Hence his self-reproach that in 1977 he was rebelling "as a writer", his letter had been "much too subjective" ("mult prea subiectivă") (31), and he had actually been "blind to the needs of his fellow citizens" ("orb la nevoile concetățenilor săi") (39). Goma's action, he concludes, "had not been intellectual or literary, but political" ("nici intelectuală, nici scriitoricească, ci politică") (51). A year before, in an interview given to Emil Hurezeanu, the motivation of this 
interpretation takes on dramatic values: "What role can literature still have in a society that has lost its moral compass, that has been deprived of its very soul?" ("Ce loc mai poate avea literatura într-o societate moral pustiită, căreia i s-a răpit sufletul?") (34). The attitude and the implicit answer pertain to the Junimist movement. Emil Hurezeanu asks a question quoted in Istoria contemporană a României (Romania's Contemporary History), a book acknowledged by Negoițescu as crucial among Maiorescu's works; it is the question addressed by minister Costaforu, who, coming from Iași, convinces Maiorescu that being in the service of literature is not enough. He inquired: "What is the use of literature, if the passivity of the politicians jeopardises the destiny of the country?" ("la ce folos literatura, dacă prin pasivitatea oamenilor politici se periclitează însăși țara? ") (35). According to Negoițescu, "The very existence of the country is currently under threat" ("România se găsește astăzi într-o primejdie de moarte") (49).

We should now dwell on an idea brought into discussion by Negoițescu in the interviews he gave during his exile years. Thinking back to the 1970s and to the isolation of the few Romanian dissidents, he mentions: "I was the most vulnerable one, as I would not do politics, because I wanted to break the chain of humility without giving up to the humiliated position of the Romanian writer, hopelessly immersed in defending his professional interests and blind to the needs of his fellow citizens" ("Eu însă eram mai vulnerabil decât toți ceilalți, fiindcă nu voiam să fac politică, fiindcă voiam să rup lanțul umilinței fără să renunț la poziția umilită a scriitorului român, pierdut în apărarea intereselor lui profesionale și orb la nevoile concetățenilor săi") (39). Of course, just like in Lovinescu's case, his refusal to do politics was actually a way of doing politics his combat for the aesthetic was a combat against the ethicist trends and, therefore, a fight for Europeanism, democracy, freedom of expression. Yet it was proven that this did not suffice. That is why he says: "I myself have underestimated the politics, and I have repeatedly said this. I was unaware of it. Only after Goma's movement did I come to the realisation of the error of my ways, as I had considered that refraining from acting on the political scene was actually doing politics. Or, unfortunately I was proven wrong" ("Eu însumi am subapreciat politicul, și am spus lucrul acesta în repetate rânduri. Nu mi-am dat seama de asta. Abia după mișcarea Goma mi-am dat seama că eu însumi eram pe o cale greșită, deoarece consideram că o politică este și faptul de a nu te manifesta politic, că abținerea de la politică este o politică. Or, din păcate, s-a dovedit că nu este așa") (48). Made in September 1989 in an interview whose summary bears the title "De la Romantism la Rezistență" ("From Romanticism to Resistance"), this statement was condensed as follows: "This a-politism had a 
political meaning and this is the traditional resistance of the Romanian writers" ("Acest a-politism avea o semnificație politică și aceasta este tradiționala rezistență a scriitorilor români") (42).

Paradoxically, when accused on account of his "aestheticism" (43), Negoițescu understands that the writer's place is right in the middle - and the praise given to the writers from 1840 is a bitter reproach to his contemporary fellow writers and to himself for this belated realization). This is what makes his Istoria / History a manifesto and this is why Negoițescu says: "The literary works examined in my book were put under scrutiny from the angle of the history lived and meditated upon day by day" (The History of Literature 9). ("Operele literare cercetate în lucrarea mea au fost citite și recitite din unghiul istoriei trăite şi meditate zi de zi" [Istoria literaturii 9]). This underlies the admiration he showed in his Istoria towards the literature of the writers from 1840, which at the time seemed to be exaggerated.

Or, the critical reception of $\hat{I}$ cunoștință de cauză (Fully Informed) is relevant from several viewpoints. Briefly, the book shocked through its radical commitment, offended because of the harsh radiography of the Romanian writers in the communist regime while the significance it attached to the comprehension of the History was dismissed.

Almost unknown nowadays, Dorin Serghie (1954 - 1998) started his review of this book from "Steaua" ("The Star") Journal (No. 5-6-7 / 1991) with the statement: "I would have never imagined that a distinguished aesthete like Ion Negoițescu could become a real rebel." ("N-aş fi crezut niciodată că un estet rasat, ca Ion Negoițescu, s-ar putea revolta cu adevărat") (17) This is, in a way, the surprise experienced also by the established critics, even if they know that Negoițescu had always been a rebel, if not "un homme révolté". Nicolae Manolescu ends his review in "România literară" ("Literary Romania") Journal by expressing his surprise at the fact that in the latest writings of Ana Blandiana, Mircea Dinescu, Dorin Tudoran "the emphasis - in Negoițescu's analyses o.n. is laid almost exclusively on the political aspect" ("accentul - în analizele propuse de Negoițescu, n.n. - cade aproape exclusiv pe elementul politic"). Hence the conclusion: "The 'aesthetic critic' we had got acquainted with from other books was supplanted here by the 'political' one. This may well be another landmark of this age" ("Political Pieces" 9). ("Criticul 'estetic' pe care-1 știam din alte cărți a lăsat în cea de față locul criticului 'politic'. E și acesta un semn al timpului" ["Texte politice" 9]).

In the book dedicated to the Sibiu Literary Cenacle, Petru Poantă rightfully notices that, in the age of communism, "the autonomy of the aesthetic 
is abolished as if it were a law that would threaten the very existence of the state. Yet the concept takes on a heroic aura, being transformed in a sort of literary equivalent to political dissidence." (The Sibiu Literary Cenacle 7) ("autonomia esteticului e abolită ca o lege care ar atenta la însăși existența statului. În contrapunct, conceptul dobândește o aură eroică, transformat într-un fel de echivalent literar al dizidenței politice" [Cercul Literar de la Sibiu 7]). The truth is that Negoitsescu had not dismissed the aesthetic criterion - although he had found himself several times in the situation to justify his changes of perspective, which were triggered by the political or axiological substance of the book and its author. After all this is also the case of the writers from 1840 about whom Negoițescu could have said what Eminescu had said in his wellknown letter to Negruzzi, justifying their appraisal he had given them in Epigonii (Epigones). Negoițescu's reluctance to politics and commitment sparked off many disputes in the 1990's. Anyway, Manolescu - who would briefly devote himself to a political career, in disagreement with the apolitical options of some of his former colleagues with whom he had supported in the communist years the aesthetic autonomy- started his review by stating, however, the organic nature of Negoițescu's attitude: "There are a few remarkable proofs of political consistency in the reasoning of the literary critic brought to light by the texts from this book" ("Political Pieces" 9). ("Sunt câteva dovezi remarcabile de consecvență politică în gândirea criticului literar, pe care textele din volumul de față le învederează" ("Texte politice" 9)). The consistency is maintained due to Manifestul (The Manifesto) from 1943 (the analysis is noteworthy "The Letter from 1943 was meant to take E. Lovinescu's defence, as he was increasingly criticised by the right-wing extremism while reasserting the place of the Romanian culture in the civilised Europe, against the primeval aggressive spirit and the autochthonists" ("Scrisoarea din 1943 era menită să ia apărarea lui E. Lovinescu, tot mai încolțit de extremismul de dreapta, și totodată să reafirme locul culturii române în Europa civilizată, împotriva spiritului primar agresiv și autohtoniștilor") (9), due to the letter of commitment to Goma's movement and to the interviews collected in this book. What led to Manolescu's reluctance is Negoițescu's harshness towards himself (Negoițescu had exposed all his weaknesses and had made three suicide attempts) and towards his fellow writers who would have stood by him nonetheless.

Negoițescu is considered just as unfair towards his fellow writers from Romania by Florin Manolescu in a review suggestively entitled "Fierul roșu" ("Branded") (published in "Luceafărul" Journal, No. 24, June the 12 ${ }^{\text {th }} 1991$ ). This collection of "political pieces" seems to him "the most vehement, the most 
committed and the most intolerant" ("cea mai vehementă, cea mai angajată și cea mai intolerantă") of Negoițescu's writings. A misconstruction which is just as inexplicable since Florin Manolescu retains the remarkable model Negoițescu had assumed, the model of the pasoptist writers who, in his own wording, "shared a sense of solidarity and bravely faced prison and even death by choosing, on behalf of the entire community, to be dismissive of the fate of their literary work." ("au cunoscut sentimentul solidarității și au înfruntat închisorile și chiar moartea dezinteresându-se, în numele întregii comunități, de opera lor literară"). After all, Negoițescu's harshness conceals his despair, patriotism, the trauma of feeling uprooted, even though we should also consider his need of something spectacular, his histrionics, his desire to shock and the pleasure he took in being uncomfortable.

More understanding is Dianei Adamek's stance, who names her review in "Tribuna" Journal (No. 9, 28.02. - 6. 03. 1991) "Povestea casei urâte" ("A tale of an ugly house"), for it does not deliver judgement nor disputes the harshness that shocked Nicolae Manolescu and Florin Manolescu. It is the tale of the house Negoițescu left when going into exile. This shows the solidarity with the critic's position. This is why she considers the political texts to reveal the inner exile, the guilty exile of the aestheticism "the spirit of our people has yielded to" ("de care s-a lăsat sedus spiritul poporului nostru"), in Diana Adamek's words, something called by Negoițescu "a form of desertion." ("o formă de dezertare") (4) The pitfall that both engulfed and helped develop most of the Romanian literature under the communist regime is the aestheticism construed as an alternative to nationalism, associated to Europeanism. This is also conveyed by Petru Poantă in the first pages dedicated to the members of the Sibiu Cenacle from the above-mentioned book, and sharply analysed by Mircea Martin in a series of articles in the magazine "22" ("Cultura română între comunism și naţionalism" ["The Romanian Culture between Communism and Nationalism"]), published in 2002. Finally, Diana Adamek offers what I would call a solidary reading and ends up her paper mentioning Negoiţescu's attitude verging on Cioranianism. "One of the ideas mentioned here is that the Romanian people is lying dormant puerilely as well as prematurely old" ("Una din ideile cuprinse aici e că poporul român somnolează, pueril și deopotrivă prematur îmbătrânit"), she says (4). The same type of reading is given by Sanda Cordoș in "Steaua" ("The Star") (no. 5-6-7 / 1991) in her text entitled "Vina noastră cea de toate zilele" ("Our Daily Guilt"). In her opinion "the political pieces" are a sequel to Un roman epistolar (An Epistolary Novel) for they might be read as sequences of a bildungsroman, "the shaping of self-conciousness" 
("formarea conștiinței-de-sine") segueing into the "shaping of consciousness of the otherness" ("formarea conștiinței-de-ceilalți") (16-7). Anyway, Sanda Cordoș does not react badly to Negoițescu's harshness that she would rather comprehend than denounce; this is why she states that, by making use of the elements of a "compared sociology", Negoițescu places the issue of the "passivity of the Romanian intelligentsia" ("pasivității intelectualității românești") in the context of the previous generations and of the other socialist countries (16-7).

After the first reviews, subjected or not to the historical period characterised by the upheaval of the 1990's, the references to the book disappear altogether. I am unaware of any subsequent research on this topic. Petru Poantă, a pundit in the political connotations of Negoițescu's criticism, fails to quote this book in The General Dictionary of Romanian Literature (DGLR). What is strange is that he had not done this in his first book about the Cercul Literar de la Sibiu (The Sibiu Literary Cenacle), a book from 1997 (published at Cluj), although he could have easily noticed the special dimension of the political texts. Firstly, starting from V. Nemoianu's book about Ș.A.Doinaș (Surâsul abundenței. Cunoaștere lirică și modele ideologice la Ștefan Augustin Doinaș [The Smile of Abundance. Poetic Knowledge and Ideological Patterns in Ștefan Augustin Doinaș's Lyrics], published at Eminescu Publishing House in 1994), he mentions the scope of the political component of the Cenacle's activity. Stating that the group "considered themselves apolitical" ("s-a considerat apolitică"), he asserts that the Cenacle had nevertheless been founded as "political and ideological-oriented" ("orientat politic și ideologic"), in the "liberal tradition" ("tradiția liberală") (Cercul Literar de la Sibiu Sibiu [ The Sibiu Literary Cenacle] 9), to which Lovinescu had largely contributed in his turn. A liberal tradition which entails a system of European values as follows: "For the members of the Cenacle liberalism means promoting the fundamental prerogatives of the democracy, of the open civil society; more precisely, this means favouring the individual liberties, the creative initiative and the professional competence" ("Concret, liberalismul înseamnă pentru ei promovarea prerogativelor fundamentale ale democrației, ale societății civile deschise; mai exact, înseamnă privilegierea libertăților individuale, a inițiativei creatoare și a competenței profesionale") (10). Moreover, Petru Poantă noticed this similitude which also applies to Istoria (The Histroy) (the privileged position of the 1848 cultural generation in the Istoria [The History] shocked, as they were named by Negoițescu modern), and the texts from În cunoștință de cauză (Fully Informed), therefore he says: "It is, therefore, amazing to see that a literary group, acclaimed as exemplary for their apolitism, is actually also clearly ideological- 
and political-oriented [...]. This liberal ideology, turned towards the west, is implacably apparent in the work of the 'aesthete' I. Negoițescu; and we are thinking, first of all, at the controversial History of Romanian Literature. Its ideologic model is Lovinescu's The History of Romanian Modern Civilisation." ("Este, așadar, uimitor să constați că o grupare literară, receptată ca exemplară prin apolitismul său, are, de fapt, o clară orientare ideologico-politică [...]. Această ideologie liberală, integral pro-occidentală, se manifestă, implacabil, în opera 'estetului' I. Negoițescu; și ne gândim, în primul rând, la controversata Istorie a literaturii române. Modelul ei ideologic este Istoria civilizației române moderne a lui Lovinescu") (15).

In his Istoria (History), Nicolae Manolescu does not bring into discussion Negoițescu's "political pieces". It is also strange that in an interview in "România Literară" ("Literary Romania") Journal, published in September 12 1 th 1991 , although he speaks, through the questions he asks, about the political commitment of the critic, the interviewer Gabriel Dimisianu ignores the book $\hat{I} n$ cunoștință de cauză (Fully Informed). The title of the interview was "Angajamentul politic al scriitorului este o problemă de etică socială" ("The Writer's Political Commitment Pertains to the Field of Social Ethics")- even if it did not go as far as to dwell on the issue of the aesthetic dimension of the political commitment.

Finally, the way in which the "political pieces" were construed is also apparent in the critical reception of Istoria (The History) which failed to mention them. Istoria (The History) was published about one year later and was not given all the attention it required: Negoițescu himself complained at one point that that his work had been superficially read. As for us, we would take it on the desert island. In cunoștință de cauză (Fully Informed) and Istoria literaturii române (The History of Romanian Literature) are considered almost incompatible, divergent, built on contrasting principles. The politician and the artist could not see eye to eye, all the more since the artist had often pleaded for the drug of beauty, for its purity (the nuancing context being simply dismissed). Anyway, $\hat{I n}$ cunoștință de cauză (Fully Informed) would be more about Negoițescu as a person, about his biographic contextual experiences, than about his vision on literature.

By way of consequence, there is not an "aesthetic" History, but one revealing a perspective all the more contextualised as the national idea was compromised in Romania by its recurrent use in the ideological propaganda. In addition to this, writing about authors and works published between 1800 and 1944, Negoițescu speaks not only about the preferences of his time, but also about the writer's social moral condition during the communist years. Istoria 
(The History) is the way it is perhaps because it was written in exile, as a backlash against the communist dictatorship from Romania. Hence the statement: "The literary works examined in my book were put under scrutiny from the angle of the history lived and meditated upon day by day" (The History of Romanian Literature 9) ("Operele literare cercetate în lucrarea mea au fost citite și recitite din unghiul istoriei trăite și meditate zi de zi"[Istoria literaturii române 9]). And the lived history implied the writer's humiliation, in the best of cases his isolation in fascination, commitment to and promotion of the aesthetic. Is there a more efficient and deceiving pitfall than the illusion of living in an ivory tower? Although it speaks about distant ages, Negoițescu's Istoria (History) - its implicit axiology, its functioning mechanism, the ideology it is founded on is a reaction to the historical events of his age. One way or another, writing about the literature between 1800 and 1944, Negoițescu reveals his attitude towards the present. The history about the times of yore is also the mirror of his own times and of his own attitude towards his times. Perhaps this is why, written on January 31 $1^{\text {st }}$ 1990, that is a few days after the events from December 1989, Negoițescu's Prefața (Preface) is a work of exile even in the sense of promoting the national idea, a manifesto like those of the 1848 generation. Yet Negoițescu's Istoria (History) is even nowadays construed as an aesthetic history, promoting exclusively aesthetic values, being noteworthy for its stylistic refinement. Negoițescu is seen as a refined jeweller of literature and a hedonist, and not an activist. Or, Istoria (History) is a manifesto pleading for the European dimension of the Romanian literature.

\section{Works Cited}

Adamek, Diana. "Povestea casei urâte" ("A Tale of an Ugly House"). Tribuna (The Tribune) Journal, no. 9 (1991): 4.

Cordoș, Sanda. "Vina noastră cea de toate zilele" ("Our Daily Guilt"). Steaua (The Star Journal), no. 5-6-7 (1991): 16-7.

Eminescu, Mihai. Opere IX. Publicistică 1870-1877 (Works IX. Journalistic Texts). Preface by Al. Oprea. Bucharest: Editura Academiei RSR, 1980.

Manolescu, Florin. "Fierul roșu" ("Branded"). Luceafărul Journal, no. 24, 12nd June, 1991.

Manolescu, Nicolae. "Texte politice" ("Political Pieces"). România literară (Literary Romania) Journal, no. 10, 7th March (1991): 9.

Manolescu, Nicolae. Istoria literaturii române. 5 secole de literatură (The History of Romanian Literature. 5 Centuries of Literature). Pitesti: Paralela 45, 1998. 
Negoițescu, Ion. "Angajamentul politic al scriitorului este o problemă de etică socială" ("The Writer's Political Commitment Pertains to the Field of Social Ethics"). Interview by Gabriel Dimisianu. România Literară (Literary Romania) Journal, no. 37 / 12th September (1991): 12-3.

Negoițescu, Ion. In cunoștință de cauză. Texte politice (Fully Informed. Political Pieces). Cluj-Napoca: Dacia Publishing House, 1990.

Negoițescu, Ion. Istoria literaturii române (The History of Romanian Literature), vol. I (1800-1945). Bucharest: Minerva Publishing House, 1991.

Poantă, Petru. Cercul Literar de la Sibiu. Introducere în fenomenul originar (The Sibiu Literary Cenacle. Introduction to the Originary Phenomenon). Cluj Napoca: Clusium, 1997.

Serghie, Dorin. "Sandala roasă din poem" ("The Dull Sandal from the Poem"). Steaua ( The Star) Journal, no. 5-6-7(1991): 17.

Stanca, Radu. Acvariu (Aquarium). Cluj Napoca: Dacia, 1971. 